\title{
Influence of parameters on the development of landslides in the Estrada de Ferro
}

\section{Vitória-Minas slopes}

\author{
Influência dos parâmetros no desenvolvimento de deslizamentos em encostas da Estradla de Ferro \\ Vitória-Minas
}

Influencia de los parámetros en el desarrollo de deslizamientos en las laderas de Estrada de Ferro Vitória-Minas

\author{
Denise de Fátima Santos da Silva \\ ORCID: https://orcid.org/0000-0002-9695-2449 \\ Universidade Federal de Minas Gerais, Brazil \\ E-mail: denisefss@yahoo.com.br \\ Rosyelle Cristina Corteletti \\ ORCID: https://orcid.org/0000-0001-6006-2877 \\ Vale S. A., Brazil \\ E-mail: rosyellecorteletti@gmail.com \\ Allan Erlikhman Medeiros Santos \\ ORCID: https://orcid.org/0000-0003-4302-3897 \\ Centro Federal de Educação Tecnológica de Minas Gerais, Brazil \\ E-mail: allanerlikhman@cefetmg.br \\ Elaine Aparecida Santos da Silva \\ ORCID: https://orcid.org/0000-0002-1246-3163 \\ Engineering Consultant, Brazil \\ E-mail: laninhambiental@gmail.com
}

\begin{abstract}
Landslides have been the object of extensive studies in the world, not only for their importance as active agents of modifications of relief forms, but also because can damages and losses to people and exposed structures, affecting various kinds of enterprises. This study had as objective the determination of influencing parameters on the development of landslides in the slopes aside of Estrada de Ferro Vitória-Minas (EFVM). EFVM is located in the southeastern region in Brazil and is an important railroad for the transportation of iron ore to the steel mills and for exportation, as well as for passenger transportation. The database used herein was collected from field work in EFVM, together with image processing and data in laboratory tests. The parameters selected to be evaluated were Atterberg limits, cohesion, friction angle, permeability and classification of soil in the slopes. Estimates were done on the volumes and areas of landslides that have already occurred in the slopes. Among the studied parameters, the results obtained for the Atteberg limits and soil cohesion were the most relevantly correlated with the field results, which is in accordance with other studies from literature. It is concluded that Atterberg limits are directly related to soil ruptures, and soil cohesion contributes to soil stabilization in slopes.
\end{abstract}

Keywords: Slopes landslides; Landslides influencing parameters; Estrada de Ferro Vitória-Minas; Multivariate statistics; Principal component analysis.

\section{Resumo}

Deslizamentos têm sido objeto de grandes estudos no mundo, não apenas por sua importância como agentes modificadores do relevo, mas também por causarem danos e prejuízos a pessoas e estruturas expostas, afetando vários tipos de empreendimentos. O objetivo deste estudo foi a determinação de parâmetros influenciadores no desenvolvimento de deslizamentos nas encostas da Estrada de Ferro Vitória-Minas (EFVM). A EFVM está localizada na região sudeste do Brasil, é uma ferrovia importante para o transporte de minério de ferro para as siderúrgicas e para exportação, bem como para o transporte de passageiros. O banco de dados aqui utilizado foi coletado a partir de trabalhos de campo na EFVM, juntamente com o processamento de imagens e dados de testes laboratoriais. Os parâmetros selecionados para serem avaliados foram limites de Atterberg, coesão, ângulo de atrito, permeabilidade e classificação do solo nas encostas. Foram feitas estimativas dos volumes e áreas de deslizamentos de terra que já ocorreram nas encostas. Dentre os parâmetros estudados, os resultados obtidos para os limites de Atteberg e a coesão do solo foram os mais correlacionados com os resultados de campo, o que está de acordo com outros estudos da literatura. Conclui-se que os limites de Atterberg estão diretamente relacionados às rupturas do solo, e a coesão do solo contribui para a estabilização do solo nas encostas. 
Palavras-chave: Deslizamentos de encostas; Parâmetros influenciadores de deslizamentos; Estrada de Ferro VitóriaMinas; Estatística multivariada; Análise de componente principal.

\section{Resumen}

Los deslizamientos han sido objeto de amplios estudios en el mundo, no sólo por su importancia como agentes activos de modificación de las formas de relieve, sino también porque pueden causar daños y pérdidas a las personas y estructuras expuestas, afectando a diversos tipos de empresas. Este estudio tuvo como objetivo la determinación de los parámetros que influyen en el desarrollo de deslizamientos en las laderas laterales de la Estrada de Ferro Vitória-Minas (EFVM). La EFVM está situada en la región sureste de Brasil y es una importante vía férrea para el transporte de mineral de hierro a las acerías y para la exportación, así como para el transporte de pasajeros. La base de datos utilizada en este trabajo se recogió a partir del trabajo de campo en la EFVM, junto con el procesamiento de imágenes y los datos en las pruebas de laboratorio. Los parámetros seleccionados para ser evaluados fueron los límites de Atterberg, la cohesión, el ángulo de fricción, la permeabilidad y la clasificación del suelo en los taludes. Se realizaron estimaciones de los volúmenes y áreas de los deslizamientos ya ocurridos en los taludes. Entre los parámetros estudiados, los resultados obtenidos para los límites de Atteberg y la cohesión del suelo fueron los más correlacionados con los resultados de campo, lo que concuerda con otros estudios de la literatura. Se concluye que los límites de Atterberg están directamente relacionados con las rupturas del suelo, y la cohesión del suelo contribuye a la estabilización del suelo en los taludes.

Palabras clave: Deslizamientos de laderas; Parámetros de influencia de los deslizamentos; Estrada de Ferro VitóriaMinas; Estadística multivariante; Análisis de componentes principales.

\section{Introduction}

Natural disasters associated with mass movements on slopes occur in a wide range of frequencies in various parts of the world. In linear infrastructures such as railways, for example, studies about landslide characteristics assume particularly relevance due to the essential nature of the project, which consists of a long trajectory crossing different regional landscapes with its distinct geological, geotechnical, topographies, and vegetation characteristics. In this context, several works were developed (Junior \& Cabral, 2019; Pedrosa et al., 2020; Santos et al., 2020; Silva \& Santos, 2020) in order to assist in decision making regarding the management and prioritization of works, not only in the railway network, but also in highways, housing complexes and in mining areas.

Landslides have been the object of extensive studies in the world, not only for their importance as active agents of modifications of relief forms, but also because of implications and for importance from the economic point of view (Guidicini $\&$ Nieble, 1984). This phenomenon can cause damages and losses to people and exposed structures, affecting various kinds of enterprises. There are different scopes for the previous studies related to slope landslides, with different objectives, for example, relationship propositions either to predict landslide volumes on slopes (Silva et al., 2018; Guzzetti et al., 2009; Guo et al., 2014; Lee \& Chi, 2011; Silva et al., 2021); classifications of landslide types (Varnes, 1978; IAEG, 1990), or identification of the events that trigger landslide development (Terzaghi, 1950).

This research was developed taking as a reference the railway called Estrada de Ferro Vitória-Minas of the company Vale S.A., which is located in the southeast region of Brazil, between Minas Gerais and Espírito Santo states (Figure 1). In 2014, the railroad handled about 100 million tons of ore, besides others cargo such as agricultural products and coal (Vale, 2018). As far as passenger transport is concerned, the railway carried almost 1 million people over the same period. 
Figure 1: Railroad location, in the Minas Gerais and Espírito Santo states.

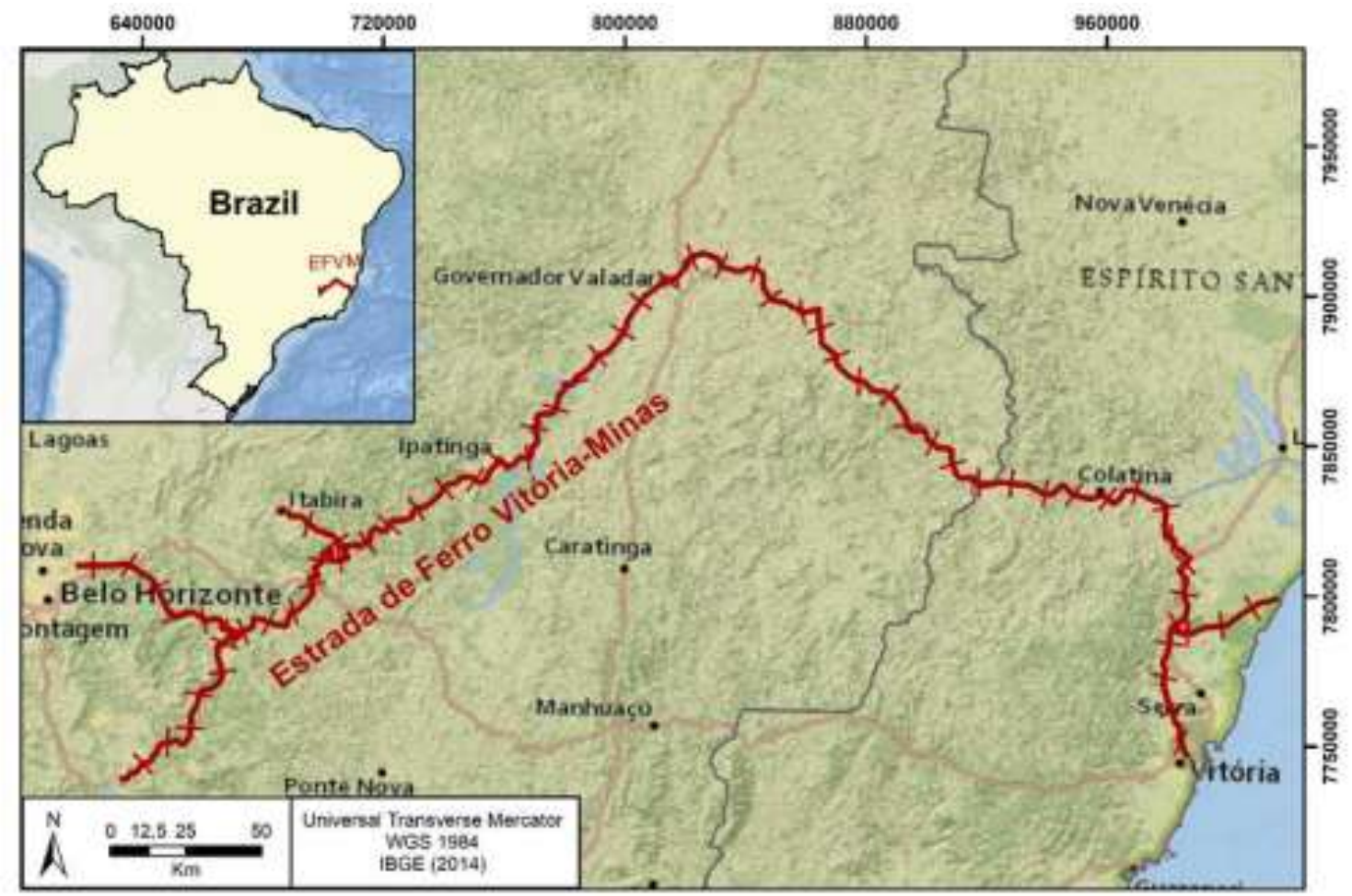

Source: Silva et al. (2020).

This study aimed to determine the influence of parameters on the development of landslides in Estrada de Ferro VitóriaMinas slopes (EFVM). The database used herein was collected from field work in EFVM, with image processing with Google Earth Pro, together with database and laboratory tests from work of Gomes (2014). The parameters selected to be evaluated were Atterberg limits, cohesion, friction angle, permeability and soil classification of slopes. To determine the occurrence of landslides in EFVM, data on the volumes and areas of landslides that occurred in the slopes were collected and estimated.

Multivariate statistical techniques have been used in the literature for different purposes. Investigation of damage from seismic events (Massumi \& Gholami, 2016), landslide susceptibility mapping (Ahmed \& Dewan, 2017) problem solving in mining (Kulatilake et al., 2012) and prevision of the stability condition of slopes (Santos et al., 2018; and Santos \& Silva, 2021) are some examples of research carried out with these techniques. Thus this work, the methodology to determine the influence of previously mentioned parameters for the development of landslides was based on techniques of multivariate statistics, such as principal component analysis. The determination of the influence of these parameters may help decision making related to measures of containment, mapping and investigation of landslides in the stretches of the road.

\section{Methodology}

The first part of the research was the use of the principal component analysis technique to the Gomes (2014) database. The variables assessed by the Gomes (2014) database are: liquidity limit, plastic limit, total cohesion, friction angle, effective cohesion, friction angle drained and permeability.

The values of area and volume of the landslide scars on the slopes studied were compared to the results of the principal component analysis, allowing the determination of the influence of these variables on the development of landslide scars on the slopes studied. Figure 2 shows the applied methodology. 
Figure 2: Flowchart of data processing procedure.

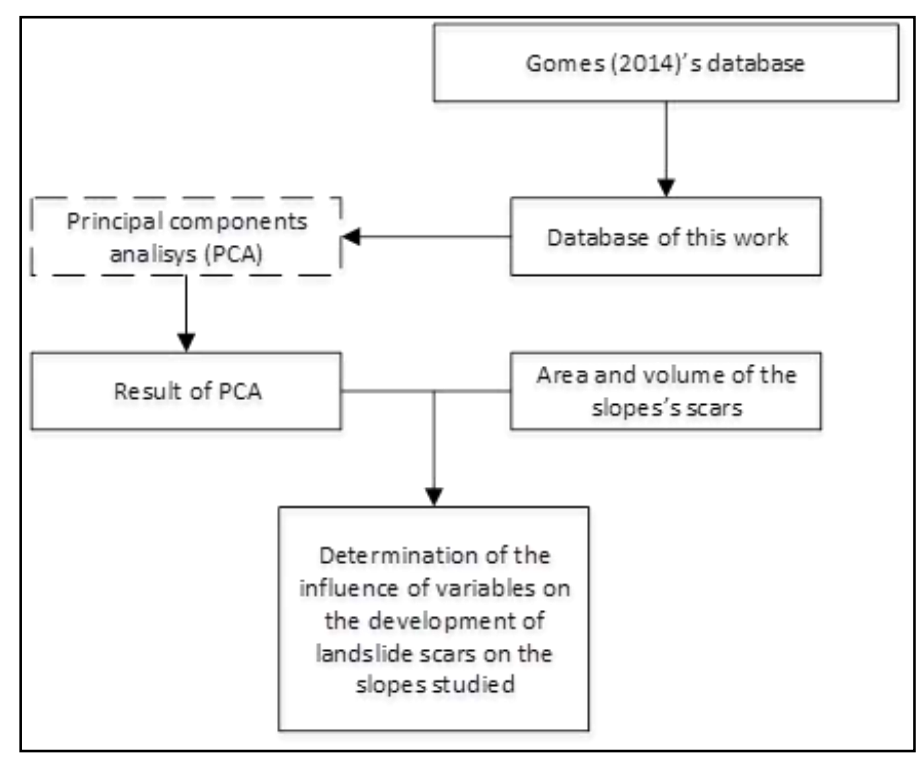

Source: Authors.

The values of area and volume of the landslide scars were estimated by imaging in Google Earth Pro together with field work on the slopes chosen for study.

The principal component analysis technique allowed the determination of the influence of the variables in the phenomena that were registered within the database by means of the element score graph together with the analysis of the eigenvectors of the original variables in each principal component generated. In addition, the technique allowed the reduction of variables by the methods of Catell (1966) and Kaiser (1958).

\section{Results and Discussion}

The database used in the present study is a result of the Gomes (2014) study, together with the addition of two other variables related to the area and respective volume of landslide scars in the slopes studied. The variables used in the database proposed by Gomes (2014) were: liquidity limits, plastic limit, cohesion, friction angle and permeability. Table 1 presents the variables used in the application of the principal component analysis.

Table 1: Variables used in the principal component analysis, all of them are classified as quantitative parameters.

\begin{tabular}{c|c|c}
\hline Parameter & Definition & Type \\
\hline LL & Liquidity limit & Quantitative \\
PL & Plastic limit & Quantitative \\
c & Coehsion & Quantitative \\
$\boldsymbol{\emptyset}$ & Friction angle & Quantitative \\
c' & Effective coehsion & Quantitative \\
ø' & Friction angle drained & Quantitative \\
e & Permeability & Quantitative \\
A & Scar's area & Quantitative \\
V & Scar's volume & Quantitative \\
\hline
\end{tabular}


In the application of the principal component analysis, the following variables were used: liquidity limit, plastic limit, coehsion, friction angle, effective coehsion, friction angle drained and permeability. The variable's area and volume of the scars were used as the results of the principal component analysis technique, aiming to investigate an influence of the other variables on development of landslides in the studied slopes. In this case, the development of landslide scars is represented by the area and volume of landslide scars.

Table 2 presents the values of the liquidity limit and plastic limit in relation to each slope studied. It is possible to observe the liquidity limit values range from 33.6 to 60.1 in the seven analyzed slopes. And the highest plastic limit values were found on the 4 and 6 slopes.

Table 2: Liquidity limit and plastic limit at each relevant slope for occurrence of landslides.

\begin{tabular}{c|c|c}
\hline Slope & LL & PL \\
\hline $\mathbf{1}$ & 43.80 & 15.20 \\
$\mathbf{2}$ & 40.80 & 17.60 \\
$\mathbf{3}$ & 33.60 & 9.40 \\
$\mathbf{4}$ & 43.30 & 24.40 \\
$\mathbf{5}$ & 44.30 & 17.70 \\
$\mathbf{6}$ & 60.10 & 30.20 \\
$\mathbf{7}$ & 50.60 & 23.40 \\
\hline
\end{tabular}

Source: Authors.

The values of cohesion, friction angle and permeability for each slope studied are presented in Table 3. The highest values of cohesion are present on 1, 3 and 5 slopes. While the highest values of friction angle are present on 2, 1 and 5 slopes.

Table 3: Cohesion, friction angle and permeability at each relevant slope for occurrence of landslides.

\begin{tabular}{c|c|c|c|c|c}
\hline Slope & $\mathbf{c}$ & $\boldsymbol{\emptyset}$ & $\mathbf{c}^{\prime}$ & $\boldsymbol{\sigma}^{\prime}$ & $\mathbf{e}$ \\
\hline $\mathbf{1}$ & 25.90 & 14.00 & 29.30 & 19.70 & 0.0001 \\
$\mathbf{2}$ & 7.20 & 20.60 & 4.77 & 33.60 & 0.0004 \\
$\mathbf{3}$ & 17.90 & 11.00 & 10.30 & 29.30 & 0.0001 \\
$\mathbf{4}$ & 5.57 & 10.60 & 4.19 & 26.10 & 0.0000 \\
$\mathbf{5}$ & 8.06 & 13.00 & 4.77 & 28.00 & 0.0001 \\
$\mathbf{6}$ & 15.70 & 12.90 & 7.73 & 32.20 & 0.0000 \\
$\mathbf{7}$ & 2.00 & 12.40 & 1.00 & 28.70 & 0.0000 \\
\hline
\end{tabular}

Source: Authors.

Table 4 presents the values of the area and volume variables of the scars on the slopes studied. It is possible to observe that the slopes with the largest landslide areas are 7 and 6. Consequently, these slopes also have the largest displaced volumes. This may be related to the fact that these slopes have the lowest values of cohesion and friction angle. 
Research, Society and Development, v. 10, n. 10, e569101019300, 2021

(CC BY 4.0) | ISSN 2525-3409 | DOI: http://dx.doi.org/10.33448/rsd-v10i10.19300

Table 4: Area and volume of the scars at each relevant slope for occurrence of landslides.

\begin{tabular}{c|c|c}
\hline Slope & $\mathbf{A}\left(\mathbf{m}^{2}\right)$ & $\mathbf{V}\left(\mathbf{m}^{\mathbf{3}}\right)$ \\
\hline $\mathbf{1}$ & 1624.9362 & 340.3258 \\
$\mathbf{2}$ & 4302.6842 & 901.1521 \\
$\mathbf{3}$ & 5451.3766 & 12559.0701 \\
$\mathbf{4}$ & 8083.9680 & 8465.5115 \\
$\mathbf{5}$ & 8174.2787 & 51360.5079 \\
$\mathbf{6}$ & 16522.7300 & 76131.2745 \\
$\mathbf{7}$ & 100336.2560 & 63043.1290 \\
\hline
\end{tabular}

Source: Authors.

The principal component analysis technique was applied in the Gomes database (2014). Thus the first results related to the application of the principal component analysis in the database are presented in Table 5, which shows the explained variance of the database for each principal component, both in individual proportion and as accumulated.

Table 5: Eigenvalue of parameters correlation matrix with the obtained proportions of occurrences explained both in individual proportion and as accumulated proportion.

\begin{tabular}{c|c|c|c|c|c|c|c}
\hline & CP1 & CP2 & CP3 & CP4 & CP5 & CP6 & CP7 \\
\hline Eigenvalue & 2.896 & 2.388 & 1.221 & 0.422 & 0.067 & 0.006 & 0.000 \\
$\begin{array}{c}\text { Proportion explained } \\
\text { Proportion explained }\end{array}$ & 0.414 & 0.341 & 0.174 & 0.060 & 0.010 & 0.001 & 0.000 \\
$\quad$ (Accumulated) & 0.414 & 0.755 & 0.929 & 0.990 & 0.999 & 1.000 & 1.000 \\
\hline
\end{tabular}

Source: Authors.

Based on the results presented in Table 5, it is noticed that with the first three principal components, it is possible to explain $92.9 \%$ of the total variability of the database. Thus the technique of the main components allows a reduction of variables of the order of $3 / 7$, considered that seven original variables were used to apply the multivariate technique.

Figure 3 shows the Screen Plot for the values of the eigenvectors for each generated component. By the Screen Plot graphic, it would be possible to apply the Criterion of Catell (1966), which guides the selection of the components by stabilizing the values of the eigenvectors. 
Figure 3: Screen plot for the seven parameters influencing the occurrence of landslides.

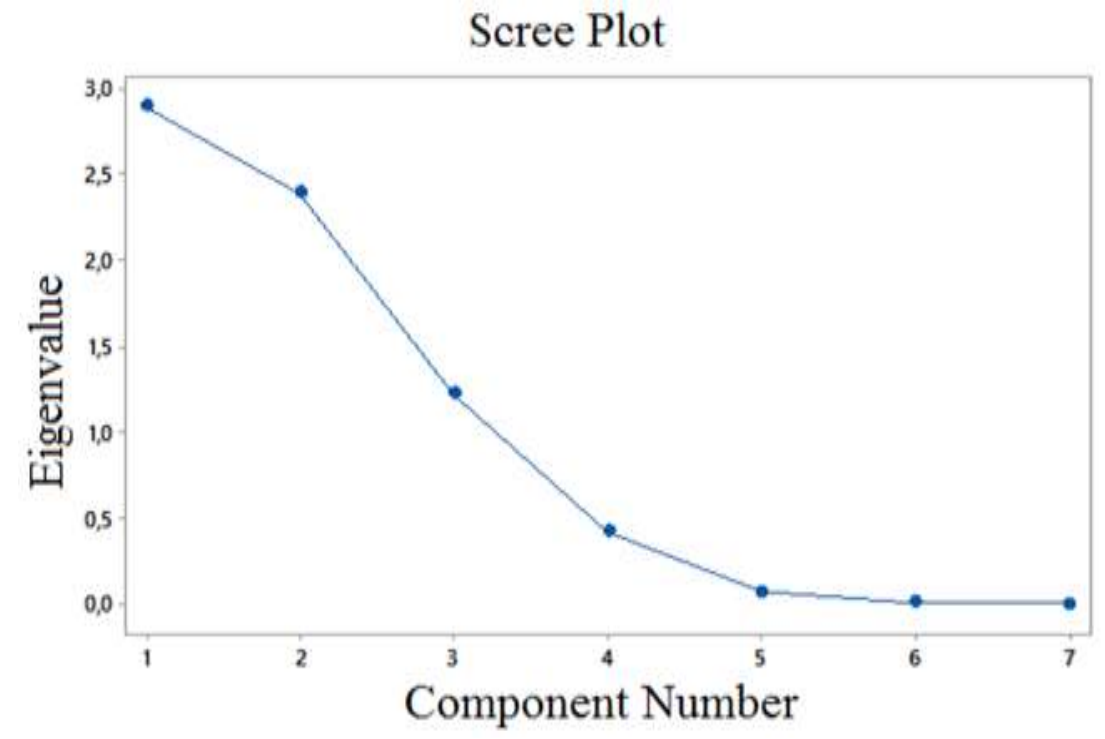

Source: Authors.

According to Kaiser's criterion (1958), the principal components are identified as those with eigenvalues greater than 1 , in order to maintain the components that explain the variability of at least one original variable. By the criterion of Kaiser (1958), the first three main components are identified that explain $92.9 \%$ of the total variability present in the database. The Table 6 shows the eigenvectors of original variables in relationship to each component generated.

Table 6: Eigenvectors of variables.

\begin{tabular}{c|c|c|c|c|c|c|c}
\hline Variables & CP1 & CP2 & CP3 & CP4 & CP5 & CP6 & CP7 \\
\hline ll & 0.265 & -0.408 & 0.553 & 0.048 & -0.589 & -0.287 & 0.157 \\
Ip & 0.371 & -0.401 & 0.374 & -0.178 & 0.720 & 0.091 & -0.062 \\
$\mathbf{C}$ & -0.488 & 0.002 & 0.373 & 0.572 & 0.199 & -0.278 & -0.423 \\
$\boldsymbol{\emptyset}$ & 0.153 & 0.515 & 0.462 & -0.282 & -0.192 & 0.379 & -0.487 \\
$\mathbf{c}$ & -0.528 & 0.014 & 0.393 & -0.066 & 0.053 & 0.455 & 0.593 \\
б' & 0.481 & 0.204 & 0.004 & 0.738 & 0.019 & 0.365 & 0.220 \\
$\mathbf{E}$ & 0.146 & 0.604 & 0.215 & -0.095 & 0.234 & -0.590 & 0.394 \\
\hline
\end{tabular}

Source: Authors.

From the values presented in Table 6, it is possible to verify the structure of the first two components, specifically CP1 and CP2. In the first component CP1, we have significant values, indirectly proportional to CP1, for the total and effective, being -0.528 and -0.488 , respectively. Still in CP1 there are directly proportional values, significant for the limits of liquidity and plasticity, being 0.265 and 0.371 , respectively.

In relation to $\mathrm{CP} 2$, liquidity and plastic limits presented significant values, indirectly proportional to $\mathrm{CP} 2$, being $-0,408$ and $-0,401$. For $\mathrm{CP} 2$, the permeability value was significant, and directly proportional to CP2, being 0.604 . Figure 4 shows the graph of the slopes studied for the first two components. 
Figure 4: Plot of the principal component scores.

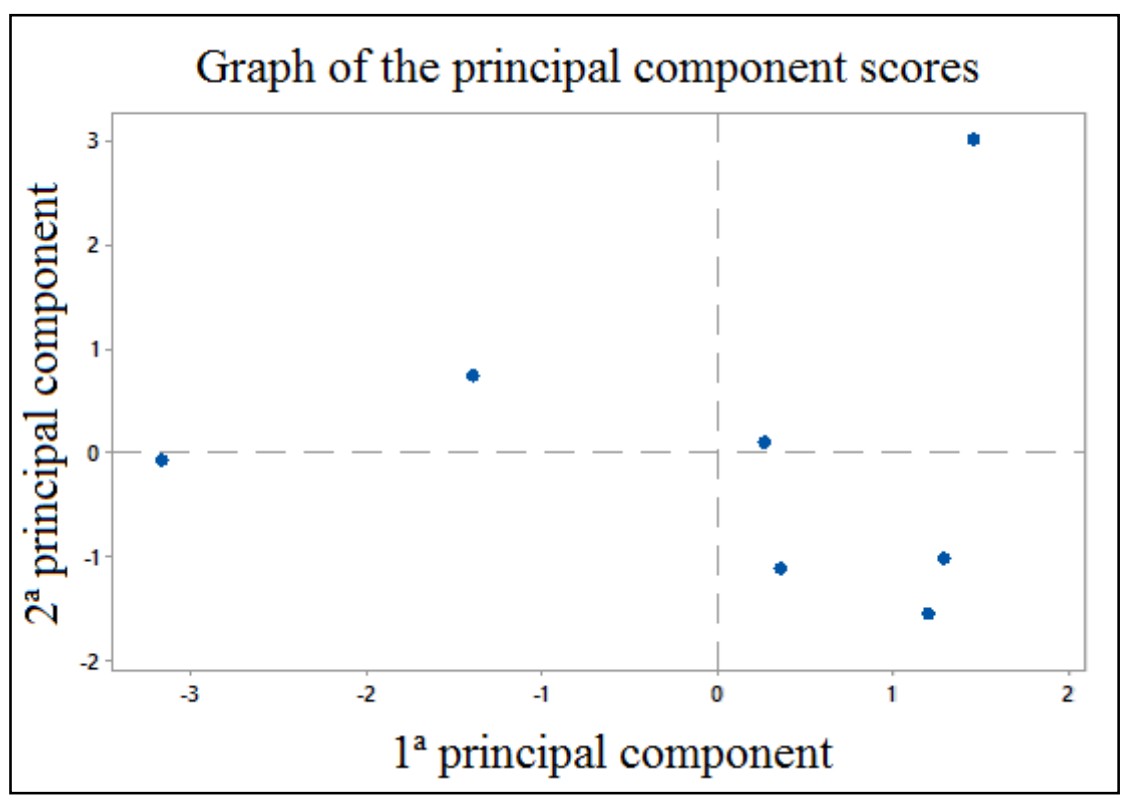

Source: Authors.

In order to allow a better visualization and interpretation of the influence of the variables on the development of scars, the scores of the principal components related to the slide scar area and the volume of the landslide scars are presented in Figures 5 and 6 , respectively.

Figure 5: Plot of the principal component scores related with groups area.

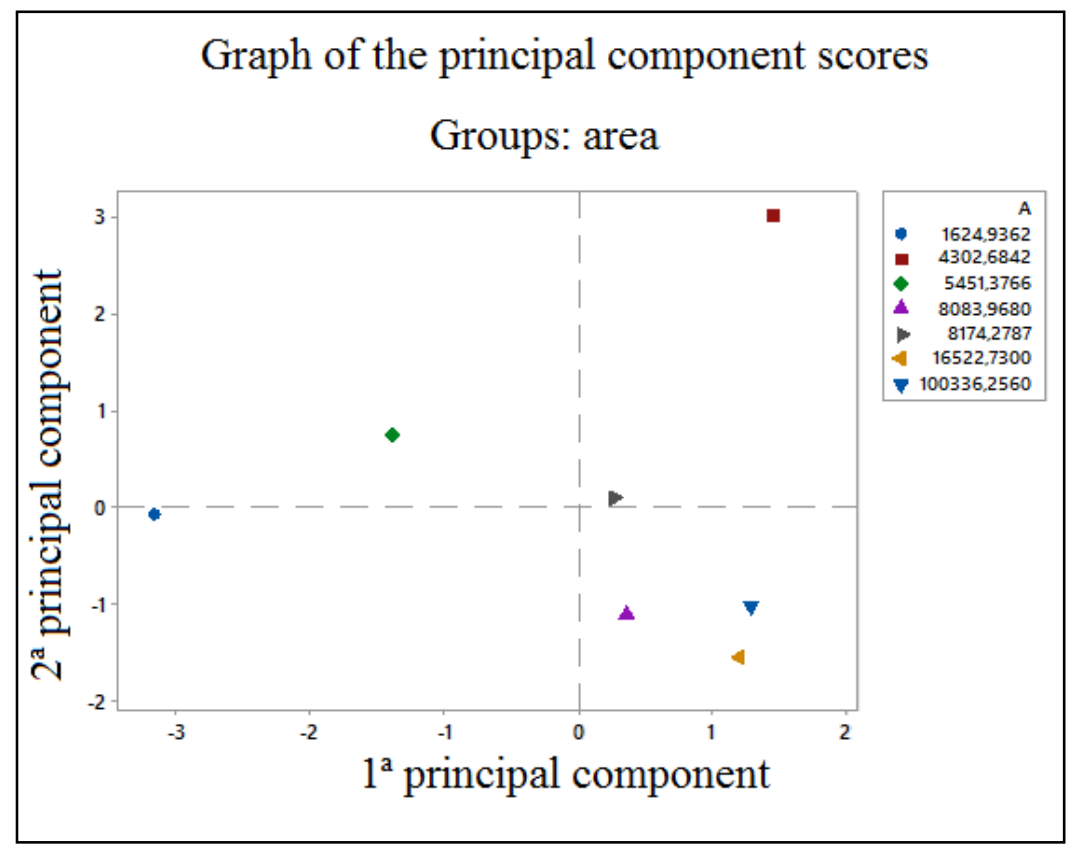

Source: Authors.

Figure 5 shows the phenomenon of development of the scar areas, by the filter of the area variable. Figure 6 shows the phenomenon of development of landslide scar volumes. 
Figure 6: Plot of the principal component scores related with groups volume.

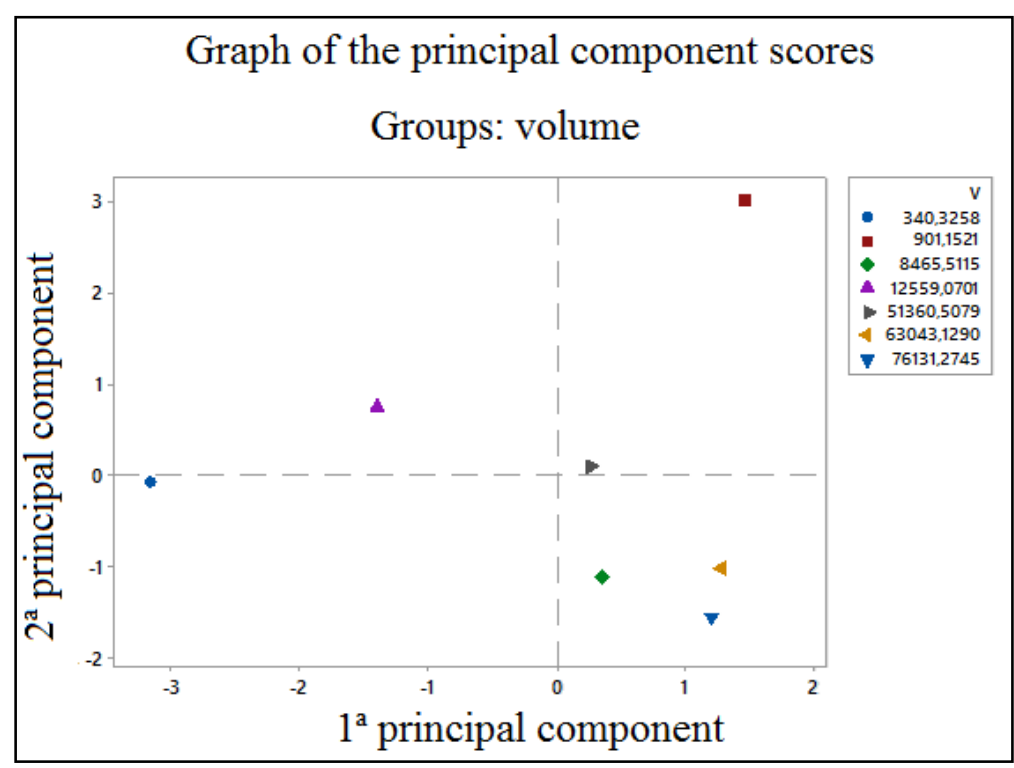

Source: Authors.

Through Figures 5 and 6, it is possible to observe the agreement of the scale of values, both for area and for volume, in groupings by the first and second principal component. The largest values for volume and area are grouped, as the smallest values are also grouped. Thus, this result allows validating the adjusted components.

\section{Conclusion}

The present research allowed the investigation of the influencing variables on the development of landslide scars in the Estrada de Ferro Vitória-Minas in Brazil, through the application of multivariate statistical principal component analysis.

Among the variables studied, the behavior of the liquidity limit and plastic limit variables were positively correlated with the development of the landslide scars. In the same structure, it was possible to observe that the total cohesion values contribute negatively to the development of the scars.

The results obtained are in accordance with the results seen in literature and in the field, where the Atterberg limits are directly related to soil ruptures. The same is true for the total cohesion that contributes to soil stabilization on slopes. For future work, it is suggested that laboratory tests be carried out on other slopes of the railway and other parameters estimated to expand the database. In addition, other techniques of multivariate statistics can be used in the expanded database.

\section{References}

Ahmed, B. \& Dewan, A. (2017) Application of bivariate and mul-tivariate statistical techniques in landslide susceptibilitymodeling in Chittagong City corporation, Bangladesh. Remote Sensing, 304:1-32

Cattell, R. B. (1966). The screen test for the number of factors. Multivariate Behavioral Research, 1, 140-161.

Gomes, R. C. (2014). Setorização Geológico-Geotécnica da Via e Avaliação e Controle de Riscos Geotécnicos dos Taludes da EFVM. Relatório Técnico Final. Ouro Preto: Universidade Federal de Ouro Preto.

Guidicini, G. \& Nieble, C. M. (1984). Estabilidade de taludes naturais e de escavação. São Paulo: Edgard Blücher - Ed. da Universidade de São Paulo. 194p.

Guo, D., Hamanda, M., He, C., Wang, Y., Zou, Y. (2014). An empirical model for landslide travel distance prediction in Wenchuan earthquake area. Landslides, 11(2): 281-291.

Guzzetti, F., Ardizzone, F., Cardinali, M., Rossi, M., \& Valigi, D. (2009). Landslide volumes and landslide mobilization rates in Umbria, central Italy. Earth and Planetary Science Letters, 279, 222-229. 
Research, Society and Development, v. 10, n. 10, e569101019300, 2021

(CC BY 4.0) | ISSN 2525-3409 | DOI: http://dx.doi.org/10.33448/rsd-v10i10.19300

IAEG. (1990). Commission on Landslides. Suggested nomenclature for landslide the International Association of Engineering Geology, 41, 13-16 pp.

Kaiser, H. F. (1958). The varimax criterion for analytic rotation in factor analysis, Psychometrika, 23, 187-200.

Júnior, H. C. \& Cabral, S. C. (2019). Tecnologias no mapeamento de áreas de risco de deslizamento em Teófilo Otoni. Research, Society and Development, 8 (12): $\mathrm{e} 018121353$.

Kulatilake, P. H. S. W., Hudaverdi, T., \& Wu, Q. (2012) New predictionmodels for mean particle size in rock blast fragmentation. Geotechnical and Geological Engineering, 30:665-684

Lee, Y. F. \& Chi, Y. Y. (2011). Rainfall-induced landslide risk at Lushan, Taiwan. Engineering Geology 123, $113-121$.

Massumi, A. \& Gholami, F. (2016) The influence of seismic inten-sity parameters on structural damage of RC buildings using principal component analysis. Applied Mathematical Modelling, 40:2161-2176

Pedrosa, A. De A., Almeida, S. M. De, \& Lafayette, K. P. V. (2020). Análise de encosta em situação de risco no município de Olinda-PE. Research, Society and Development, 9 (11): e3499119817.

Santos, A. E. M., Lana, M. S., Cabral, I. E., Pereira, T. M., Naghadehi, M. Z., da Silva, D. F. S., \& dos Santos, T. B. (2018). Evaluation of rock slope stability conditions through discriminant analysis. Geotechnical and Geological Engineering, 37, 775-802.

Santos, A. E. M. \& Silva, D. F. S. (2021). Stability conditions evaluation of slope by multivariate analysis. Holos. 37 (3), 1-13.

Santos, A. E. M., Silva, D. De F. S. Da, Mendonça, G. A., Santos, T. V., Amaral, R. R., \& Silva, L. A. M. (2020). Índice de queda de blocos e caracterização geológica-geotécnica em taludes rodoviários: um estudo de caso na BR-262. Research, Society and Development, 9 (12): e12891210968.

Silva, D. F. S., Corteletti, R. C., Filgueiras, R. A. C. Santos, A. E. M. (2021). Correlations between landslide scars parameters using remote sensing methods in the Estrada De Ferro Vitória-Minas, southeastern Brazil. Revista Brasileira de Geomorfologia, 22 (2): 297-314.

Silva, D. De F. S. Da \& Santos, A. E. M. (2020). Rockfall hazard assessment and geological-geotechnical characterization of a rock slope in BR-356. Holos. 36(8), 1-13.

Silva, D. F. S., Santos, A. E. M., Ferreira, B. T., Pereira, T. M., \& Corteletti, R. C. (2018). Cluster analysis for slope geotechnical prioritization of intervention for the Estrada de Ferro Vitória-Minas. REM - International Engineering Journal, 71 (2):167-173.

Terzaghi, K. (1950). Mechanisms of Landslides, Geotechnical Society of America, Berkeley, 83-125.

Vale. (2018). Sobre a Vale. Notícias. <http://www.vale.com/brasil/PT/aboutvale/news/Paginas/ferrovia-vitoria-minas-transportou-119-milhoes-toneladas-cerca1-milhao-pessoas-2014.aspx>.

Varnes, D. J. (1978). Slope movement types and processes. In: Landslides and Engineering Practice. 